\title{
Online Diagnose System for Risk of Kidney Failure
}

\author{
Noraziah Mohd Noh ${ }^{1}$, Zalmiah Zakaria ${ }^{1, a}$, Shahreen Kasim² \\ ${ }^{1}$ Fakulti Sains Kompute dan Sistem Maklumat, Universiti Teknologi Malaysia, Johor, Malaysia \\ ${ }^{2}$ Fakulti Sains Komputer Dan Teknologi Maklumat, Universiti Tun Hussein Onn Malaysia, 86400 Parit Raja, Batu Pahat, \\ Johor, Malaysia \\ azalmiyah@utm.my
}

ARTICLE INFO

Article history

Received June 2019

Revised July 2019

Accepted August 2019

Keywords

\begin{abstract}
Renal or kidney failure, only a few citizen alert in this renal failure problem. They have a lot of thing to done, and disregard on their healthy matter, especially on organ healthy that it cannot be see directly on our eyes. On that matter, online Diagnosis Renal Failure system is developed to help society to diagnose their healthy on renal failure view. System is developed online to give an advantage to society to achieve or access the system everywhere. System has two major module, diagnosis module and information module. Diagnosis module is the part where the user can make a diagnose. Information module has two sub modules, information on renal failure and information on dialysis center all around city in peninsular Malaysia. The system development is performed on expert system methodology with prototyping as the model. Production rules technique is used to represent knowledge and for searching process pattern matching technique has been use. The system expectantly can give a benefit to society and performing diagnosis in represent the knowledge of expert in medical field.
\end{abstract}

\section{Introduction}

In this cyber world era, Malaysians are increasingly seeking opportunities to improve their standard of living in line with the increasingly advanced world community. The hustle and bustle of the daily life of the community results in certain things that will be neglected.

Health is one of the obvious human forgetfulness. The health of children is less concern to the public. Public opinion, as long as they are able and capable physically to perform a task they are classified as healthy individuals. Adult community now, easily satisfied and often ignores health. Way of life that should not have become routine in the life of society.

A developed country is a country that has a population that is concerned and aware of the environment and the health of surrounding communities. They will give priority to family health and also the health of themselves. They will always maintain the intelligence of the body to be sure of being able to compete with the world community. Therefore internal health concern should be emphasized.

In this project, it has focused on one of the most important human organs, the kidneys. Kidney failure is something that will not be noticed by the naked eye. A last resort for those who suffer from kidney failure are living like normal is to make treatment 'hemodialysis'. This treatment should be done by the patient until the patient's life can do a kidney transplant have been donated to patients. 
For working individuals, this is the nightmare experienced by them and certainly difficult for them to accept. In fact not only for working individuals as well as the whole society, they certainly do not want to depend on a machine that acts to cleanse the blood of the engine 'Hemodialysis' throughout their lives. All this must be avoided, where prevention is better than cure.

The system to be developed is to bring awareness to the community about their health, and also to enlighten them about the practices of good health and prevention should be taken in advance to ensure they are in a satisfactory state of health.

\section{Literature Review}

Review background of the problem is created after the objectives, scope and statements identified problems. Background study is important to enable us to understand the problem domain in detail.

\section{A. Domain Background}

The kidney is the most important organ in the human body. Ranking kidney is on the left and right 'lumbar spine (between the thorax and vertebrae). The position of the right kidney lower than the left kidney due to its heart set on it.

Kidneys are covered by the 'tough capsule' and are surrounded by a 'cushion of fat' and supported by 'fasciae'. The kidneys are protected by the abdominal muscles, fasciae, fat and intestines.

The kidneys have a width of between 6 inches to 7 inches and a height of 10 centimeters to 12 centimeters and a thickness of 2 to 3 centimeters. Each adult kidney weighs 120 grams up to 170 grams. It can also be said that the kidney represents our own hands and shaped like beans.

The normal kidney intertwined a very complex task. One-fifth $(1 / 5)$ of the amount of blood pumped by the heart goes through both kidneys. Kidney function for the water balance in the body, remove toxic slums, form new red blood cells, bones and also control the content 'elektrolite' and acid / base.

There are several symptoms of kidney disease prefixes that can be seen of them which includes the skin color that looks gray and pale and yellowish, rough surface skin, nails are thin and fragile, mouth swelling, eyelid swelling, urinary incontinence, water color turbid urine and frequent shortness of breath. Kidney disease also involves the descent but the percentage is very low. For those who have diseases such as diabetes, hypertension and infection, the risk of kidney failure is very high.

However, kidney failure can occur either suddenly or slowly. Usually both kidneys will fail simultaneously. If one of the kidneys are working normally, then it can still survive to continue a normal life. Generally when the kidneys fail to function until more than $90 \%$ then, patients should undergo 'dialysis' before proceeding further treatment options.

Dialysis treatment is a treatment for patients which can be categorized as chronic renal failure. It is a treatment to clean the blood or in other terms is to wash the blood. Dialysis treatment using a machine that is the role of the hemodialysis machine to wash the blood of kidney patients. It is as false to the patient's kidneys and plays like a kidney. Toxic substances and waste products that can not be removed from the patient's body will normally removed during dialysis.

The last treatment that can be done is to do a kidney transplant.

\section{B. Reviews on Similar System}


The existing system is a manual system that must be passed to obtain a patient's examination. At the beginning the doctor will ask some questions to the patients as a way of life practiced, medical history, whether the patient has experienced or is experiencing other diseases. Then the doctor will perform a physical examination, urine tests and blood tests. This was the beginning before the doctor can confirm the disease of the patient.

After the disease was confirm for suffering kidney failure, intensive care will be carry out.

\section{Methodology}

Knowledge-based prototyping methodology is used in developing this system. While the model chosen for the methodology is a prototype model. This model was selected because it is suitable for large projects with a limited cost. This model can also give the user a complete overview about the current state of the system.

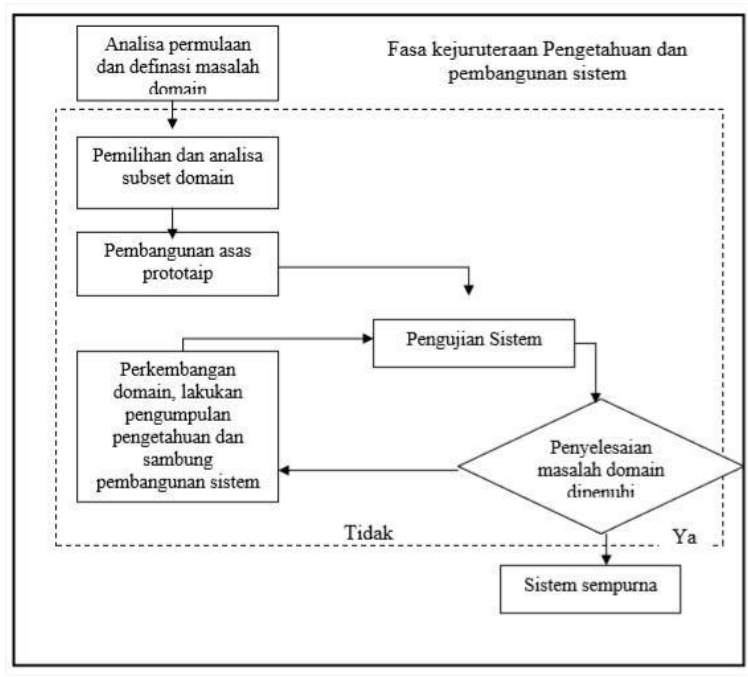

Figure 1: Prototype Model For Expert System

When developing the system, user typically can not provide a full specification of the desired requirements. Therefore, using this model, the system will continue its development despite the user requirement specifications are incomplete because this model allows the repetition phase is done.

An expert is required to participate actively in the development. Therefore, the user requirement can be identified and enhanced by stages. Comments and opinions from specialists can be recognized for producing the new version. Next, the new prototype is tested and improved until both are satisfied with the system developed.

\section{A. Study on Selected Methodologies}

The methodology chosen to develop this expert system is an expert system methodology and model protataip. Figure 2 below shows the workflow for each phase of the prototype methodology. 


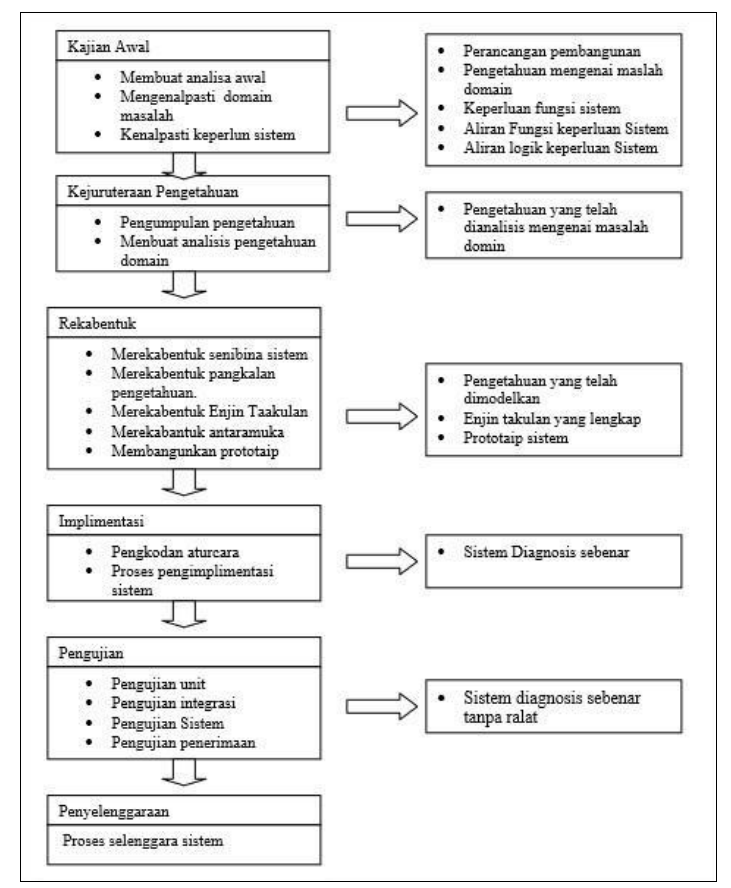

Figure 2: workflow for each phase of the prototype methodology

Table 1: Phases in Selected Methodology

\begin{tabular}{|c|c|}
\hline PHASES & ACTIVITIES \\
\hline Early & $\begin{array}{l}\text { 1. Make an initial analysis } \\
\text { 2. Define and identify the problem domain } \\
\text { 3. Review the system requirements } \\
\text { 4. Project objectives and scope of the } \\
\text { project identified and listed } \\
\text { 5. The goal of the project is determined } \\
\text { 6. Domain problem is identified, studied } \\
\text { and analyzed in details } \\
\text { 7. System requirement are identified and } \\
\text { modeled in UML }\end{array}$ \\
\hline Knowledge Engineering & $\begin{array}{l}\text { 1. Collecting knowledge and analyzing data } \\
\text { obtained } \\
\text { 2. Understanding the domain concepts are } \\
\text { enhanced, analyzed and studied. } \\
\text { 3. Checking is done by domain experts for } \\
\text { confirmation }\end{array}$ \\
\hline Design and Development & $\begin{array}{l}\text { 1. Designing system architecture, structural } \\
\text { system, design knowledge and reasoning }\end{array}$ \\
\hline
\end{tabular}




\begin{tabular}{|l|l|}
\hline & engine and the interface system \\
\hline Implementation & $\begin{array}{l}\text { 1. Program coding is carried out } \\
\text { 2. System carried out in real environment } \\
\text { using real data } \\
\text { 3. System documentation }\end{array}$ \\
\hline Testing & $\begin{array}{l}\text { 1. Unit testing } \\
\text { 2. Integration testing } \\
\text { 3. System testing } \\
\text { 4. Acceptance testing }\end{array}$ \\
\hline
\end{tabular}

\section{System Analysis and Design}

Diagnostic Imaging Management System at Batu Pahat Hospital will be implemented and the system will store all the information in the system.

The main goal in the requirements phase is to identify the specifications of the requirements in system development. Use-Case modeling is used to describe the development workflow to assist in the process of understanding and designing the system.

\section{A. Use Case Model}

Use-case is intended to describe the overall relationship between classroom interactions of the system with the actor. The scenario also represents a special set of interactions between certain objects with users. Use-case model that was produced is explained throughout the entire process as input to the next phase of the task and verify the model.

Digital systems use-case involves two actors, namely the system which plays an important role and is an individual who has been a major focus of the project and also admin.

As Figure 3 shows the relationship between functional in the system and the user. The main functions available in the system is to allow the user to make a diagnosis, get a diagnosis and advice from diagnosis. In addition, the system also provides information that displays information about kidney failure, dialysis center information as well as information systems knowledge ReFDS as a reference to users. 


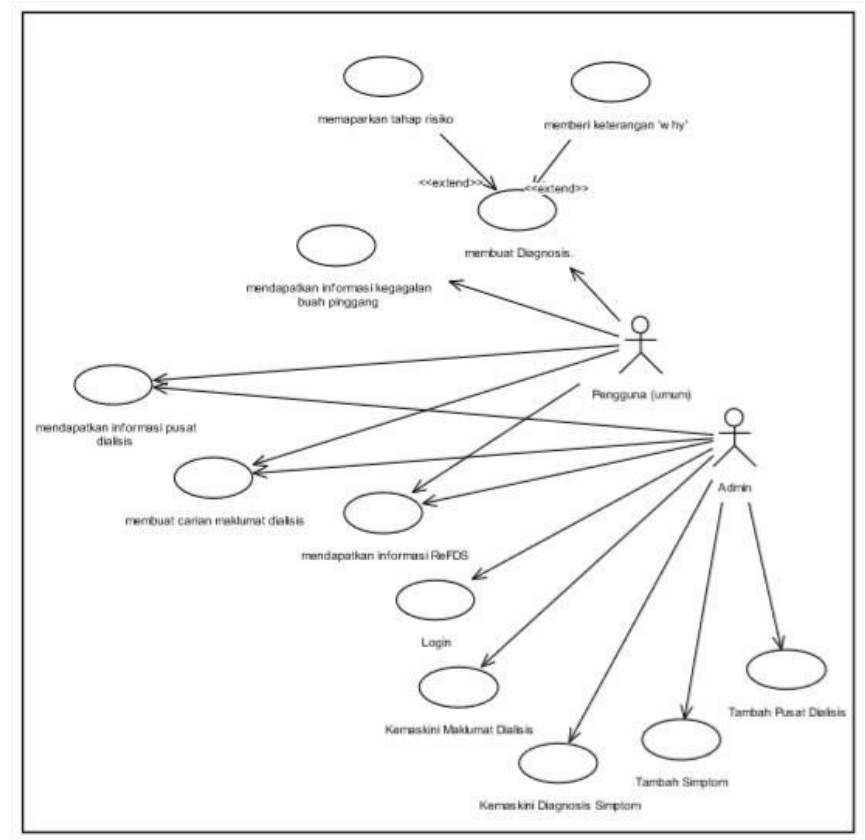

Figure 3: Use-Case For The Whole System

The Use-Case diagram is modeled to illustrate the functions contained in the system. Description of use-case can be seen in table 2 and table 3 .

Table 2: Description of Use-Case For User Actors (general)

\begin{tabular}{|l|l|}
\hline \multicolumn{1}{|c|}{ Use Case } & \multicolumn{1}{c|}{ Descriptions } \\
\hline $\begin{array}{l}\text { Getting information } \\
\text { about kidney failure }\end{array}$ & $\begin{array}{l}\text { This function allows the user to get information about kidney failure or } \\
\text { kidney disease, it also provides information on the treatment required by } \\
\text { patients and health care information for patients with kidney. }\end{array}$ \\
\hline $\begin{array}{l}\text { Getting information } \\
\text { about Dialysis } \\
\text { Center }\end{array}$ & $\begin{array}{l}\text { This feature provides a list of the Dialysis Center found that urban towns in } \\
\text { Peninsular Malaysia paneled workers' compensation insurance. In this } \\
\text { functionality, users can get brief information about the desired dialysis center. }\end{array}$ \\
\hline $\begin{array}{l}\text { Search information } \\
\text { dialysis }\end{array}$ & $\begin{array}{l}\text { This function is intended to make it easier for users to access information } \\
\text { easily, by doing a search by state and city. }\end{array}$ \\
\hline $\begin{array}{l}\text { Getting information } \\
\text { ReFDS }\end{array}$ & $\begin{array}{l}\text { This function module provides system usage to users, and the introduction of } \\
\text { the system. }\end{array}$ \\
\hline Making diagnosis & $\begin{array}{l}\text { This function requires the user to answer a set of questions that have been } \\
\text { provided. The calculation of the level of risk incurred on a combination of } \\
\text { questions sent to the user. The input is then sent to the knowledge base for } \\
\text { processing the diagnosis. }\end{array}$ \\
\hline $\begin{array}{l}\text { Displays the level } \\
\text { of risk }\end{array}$ & $\begin{array}{l}\text { This function displays the risk level based on the results of the diagnosis } \\
\text { made by a user. }\end{array}$ \\
\hline Testifying 'WHY' & $\begin{array}{l}\text { Functional submissions 'why' is a function that provide information and } \\
\text { explanations for each question to be answered by the user }\end{array}$ \\
\hline
\end{tabular}

Table 3: Description of Use-Case For Admin Actors

\begin{tabular}{|c|l|}
\hline Use Case & \multicolumn{1}{c|}{ Descriptions } \\
\hline Add Dialysis & This functionality, allowing administrators to add a new dialysis center to the \\
\hline
\end{tabular}


Vol. 1, No. 1 July 2019, pp. 48-67

\begin{tabular}{|l|l|}
\hline Center & database. \\
\hline Add Symptoms & $\begin{array}{l}\text { This functionality, allowing administrators to add new symptoms to the } \\
\text { knowledge base. }\end{array}$ \\
\hline $\begin{array}{l}\text { Updating } \\
\text { information on } \\
\text { Dialysis }\end{array}$ & $\begin{array}{l}\text { This feature allows administrators to manipulate data contained in the } \\
\text { database, whether to update the existing dialysis and dialysis eliminate } \\
\text { information. }\end{array}$ \\
\hline $\begin{array}{l}\text { Update Diagnosis } \\
\text { Symptoms }\end{array}$ & $\begin{array}{l}\text { This function is provided is intended to facilitate updating the admin or } \\
\text { domain expert symptom stored in the knowledge base and also allows } \\
\text { administrators to easily eliminate symptoms. }\end{array}$ \\
\hline $\begin{array}{l}\text { Search information } \\
\text { dialysis }\end{array}$ & $\begin{array}{l}\text { This function is intended to make it easier for administrators to access } \\
\text { information easily, by doing a search by state and city. }\end{array}$ \\
\hline $\begin{array}{l}\text { Getting information } \\
\text { ReFDS }\end{array}$ & This function provides the use of learning modules to system admin. \\
\hline Login & Users only have to enter the admin password system manipulation. \\
\hline
\end{tabular}

\section{A. Activity Diagram}

Activity diagrams show the activities available in each function in the system. General activity diagram, Figure 4 is a diagram for users and administrators get full access.

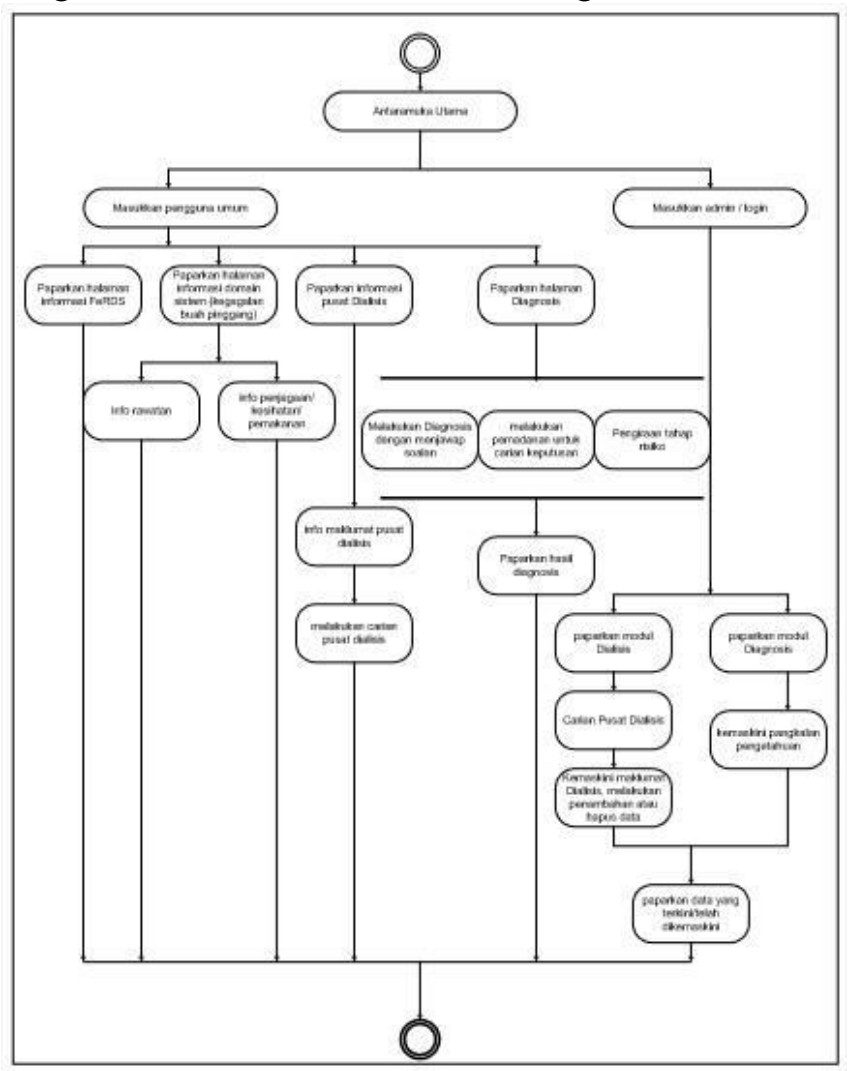

Figure 4: General Activity Diagram - Full Access.

\section{B. Analysis Phase Workflow}


The main purpose of an analysis is to move the requirements of the system to a form that can map well to the task of software designers. The process is based on use-case diagrams are generated. Figure use-case is described in detail using the sequence diagram. The sequence diagram can be found in Appendix A.

\section{Workflow of Knowledge Engineering Phase}

Knowledge engineering phase focuses the activities of collecting, reviewing and analyzing the knowledge of experts and other sources. The collection of information is a method of interviews with experts, information search side of literature and internet search of resources as well as a variety of sources that can provide information.

The knowledge gained is collected and examined to make a detailed analysis and then get confirmation from a specialist. Understanding the basic concepts of domains and checks carried out to ensure all the necessary knowledge has been obtained before the process design knowledge base implemented.

\section{Workflow of Design Phase}

The design phase is the next phase after phase of analysis and knowledge engineering phase. Design Phase is divided into two main parts which are the logical design and physical design. Design logical logically gives a true picture of the entire project as well as the processes involved. It is represented in the form of diagrams and models and their earnings using Unified Modeling Language (UML). Physical design is also more focused on system design. Such as architectural design, component design and system interface design.

\section{E. Database Design}

This design is done in the construction phase. Database design is necessary to help the understanding of the semantic meaning of the data and understand the information needs ReFDS system. Among the activities involved in designing a database is to identify the major components of the system through the collection and analysis of diagnostic information. Databases built in the development of the system is intended to keep the information symptoms, keep patents results, diagnosis information, storing information admin, and store information centers dialysis. Database system can be found in Appendix B.

\section{F. Workflow of Testing Phase}

Workflow phase of testing is intended to test the developed system can provide results that are generated to match the expected results. Testing is done by executing the program under test with a test case. The results of these tests assessed whether the program being tested meeting the requirements.

The purpose of the test is to detect mistakes or errors in the program, to ensure that the system can function properly. Tests performed on the test system are a black box and white box testing. The testing result can be found in Appendix C.

\section{Implementation and Testing}


The implementation process is to code the program activities that have been implemented in accordance with the specifications in the design phase.

\section{A. Development of Database Relationship}

In building the database, MySQL application is used to build a database system. MySQL applications run on the Apache Web server is "http: // localhost / phpMyAdmin /" The interface is easy to understand can facilitate developers to build database compared to a database within the reach of DOS.

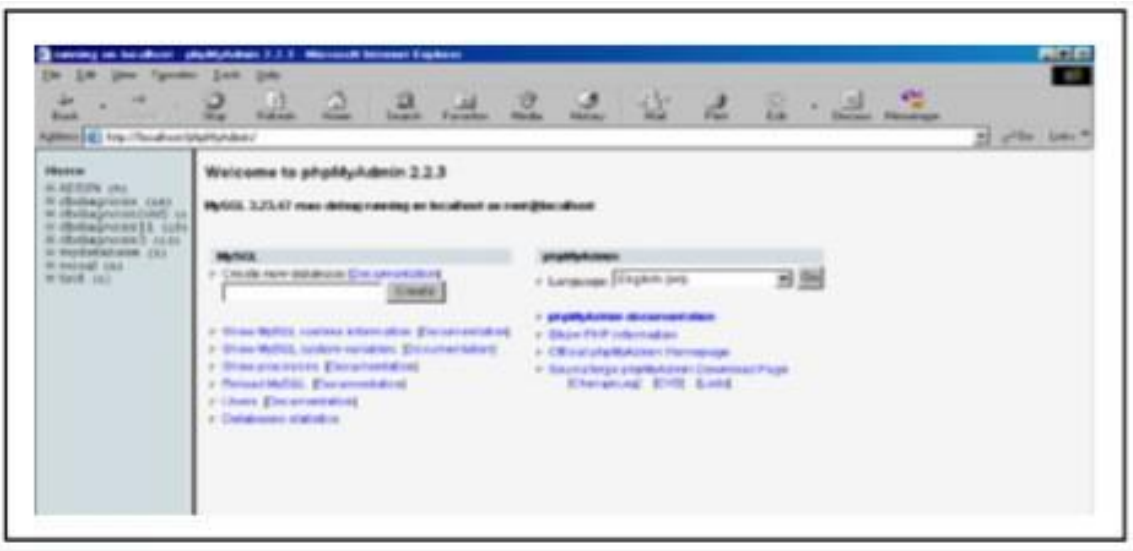

Figure 5: phpMyAdmin Website to Build Database

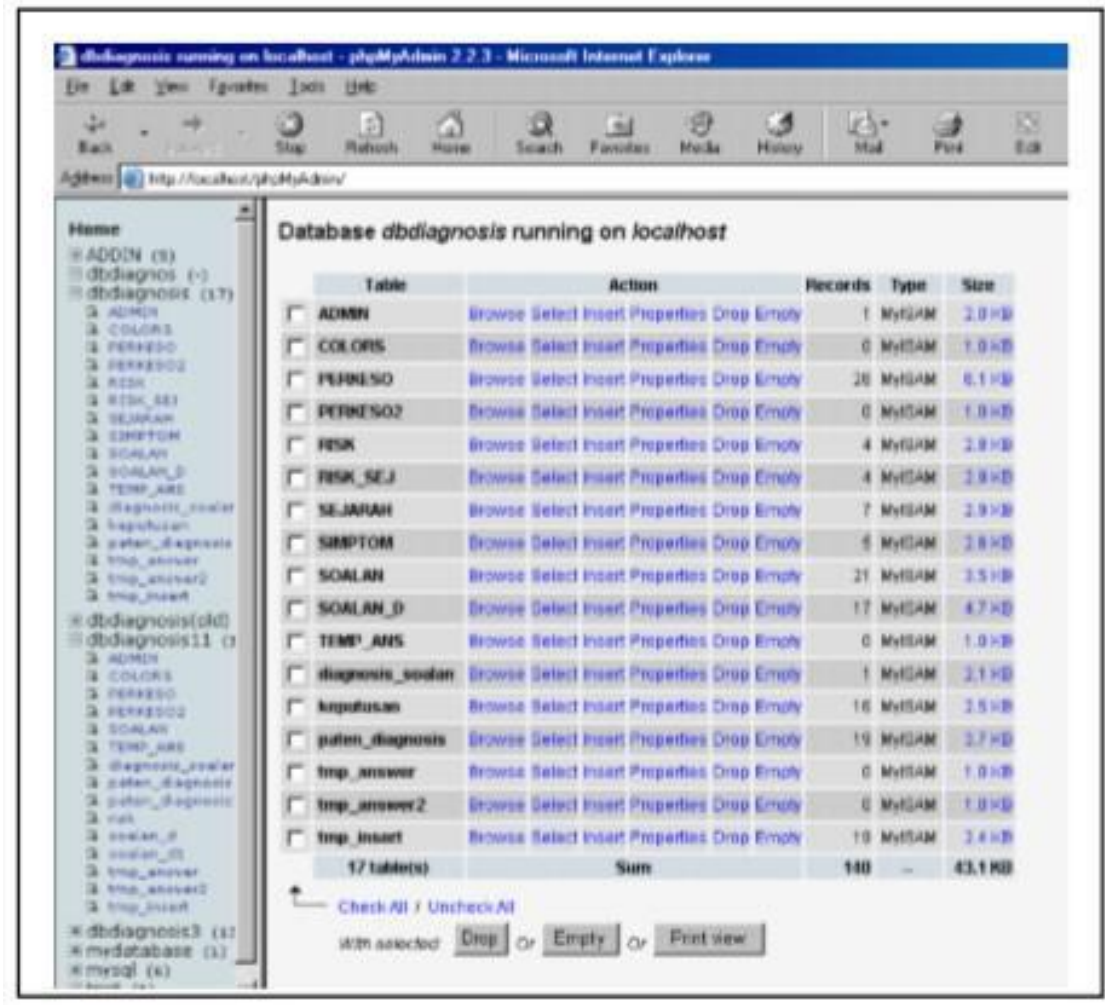

Figure 6: Website showing Table Build in 'dbdiagnosis' Database 
Among the most significant advantages to choosing MySQL as a database is a developer does not need to build a data source (data source) ODBC.

\section{A. Example of Input/Output Result}

The system is divided into two main parts, namely the common user and admin section. In the general user, the information can be accessed by all users, without requiring them to register, and so to make the diagnosis. General users do not have to go through user registration system.

On the admin side, the user is recognized by admin only be able to enter this section, it seeks to ensure that data and information in the system is correct and not be manipulated by the irresponsible and uninformed about the domain system development, namely, kidney failure as well as list dialysis centers throughout Malaysia yan paneled Perkeso.

Some examples of the inputs and outputs are shown in the figure below. Figure 7 is the display of the dialysis center search function. The field chosen here is the City. Figure 8, the display screen shows the results of the function information center dialysis using the search key cities.

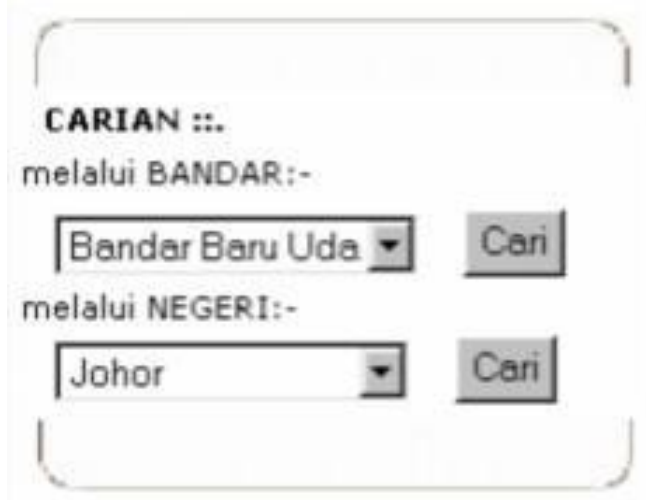

Figure 7: Display Menu for Searching

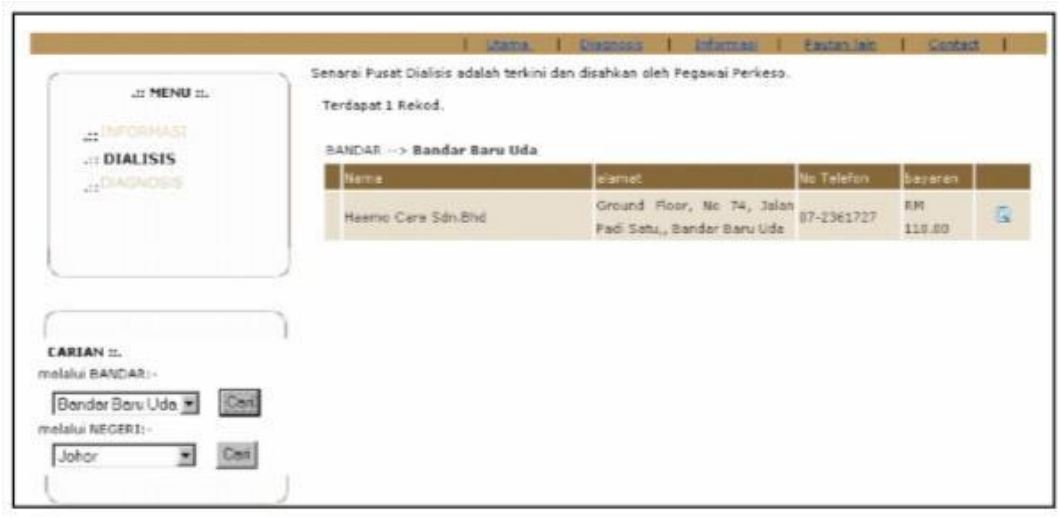

Figure 9: Search Results By The State

Figure 10 is the interface diagnosis. Users need mejawap options, either 'yes' or' no 'for an answer or leave the space blank if you do not have or do not have symptoms that otherwise .. To give an understanding to the user, a link is provided info, Link will display info arguments' why the question would be displayed in the room info. 


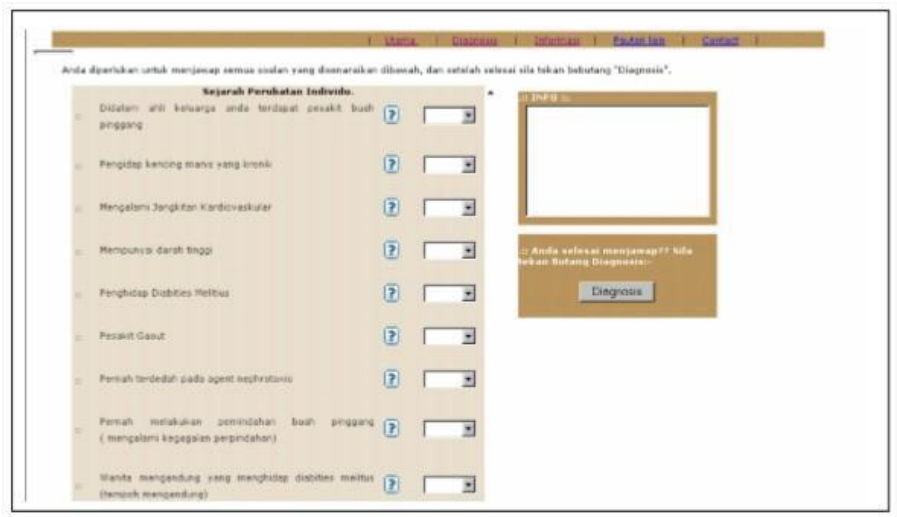

Figure 10: Interface of Diagnosis

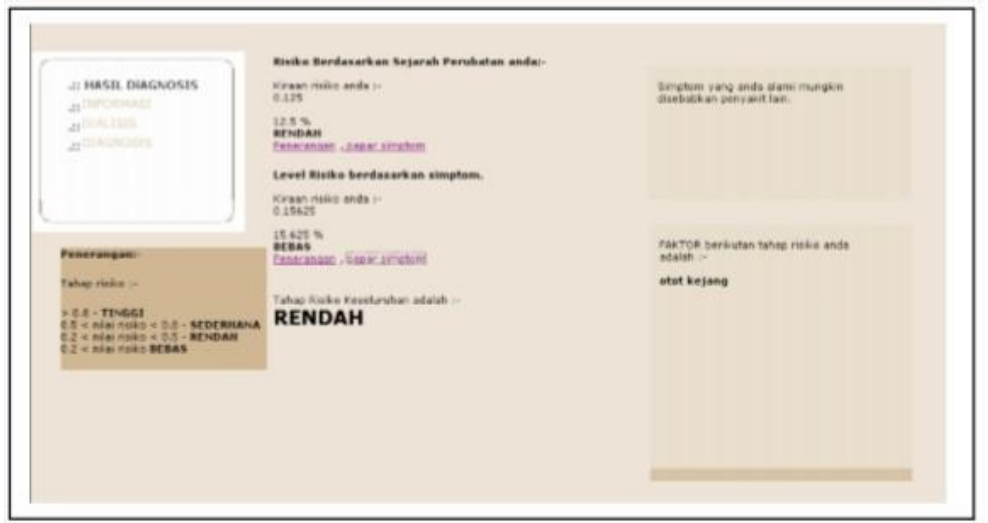

Figure 11: Display of Interface for Diagnosis Result

With full admin access to the system, as described in the previous topic, admins can perform additional symptoms to diagnosis module and can also make additional information on the dialysis module. Figure 12 shows Admin Menu. Figure 13 shows the interface for increased symptoms.

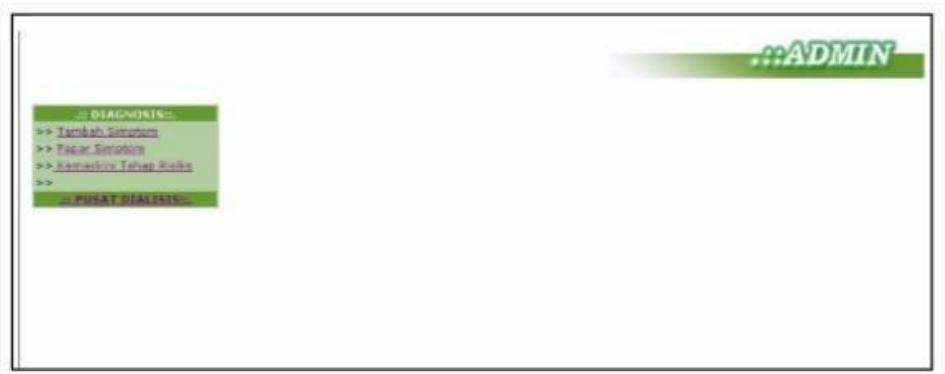

Figure 13: Interface of Admin Add Symptoms

Figure 14 is the display after symptom is added to the knowledge database. 


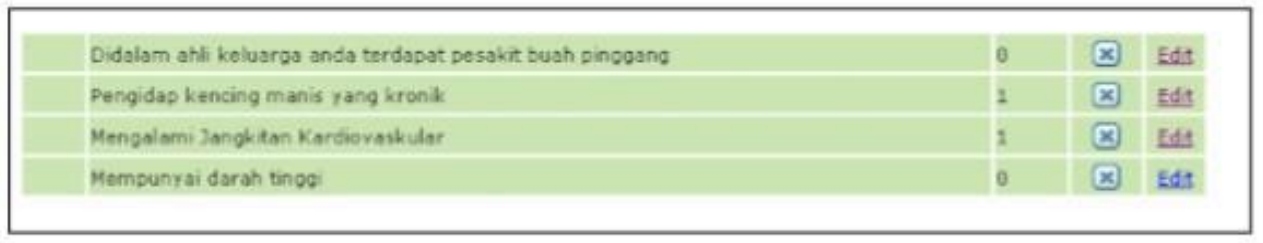

Figure 14: Display of Symptom Interface

Figure 3 shows the of Diagnostic Imaging Department Management System for the Staff Information Module.

\section{Conclusion and Future Works}

Overall, the expert system developed using patent-matching can be generated and produce expert systems in PHP development environment.

This system has met the objectives, goals and scope outlined at the beginning of development. All the plans that have been proposed at the beginning of the planning system have been running smoothly, although there are obstacles in developing this system.

The system is capable of providing an appropriate decision based on the symptoms that have been listed, as well as providing information about kidney failure in Malay Language.

In addition, the conclusion can be made after the developers strive to complete this project is the result of the study and implementation of this framework, many give exposure to the developer, especially to develop a system. It is such a developer can add knowledge besides involves themselves into trying something new. Valuable experience gained, will serve as a guide to developers to improve them towards a more organized and systematic.

\section{References}

1. Azah Kamilah Muda, Hidhamudin Asmuni, mohd razak samingan, nor bahian Hj. Ahmad, Norsham Idris, Puteh Saas, Radziah Mohamad, Shahliza Andul halim dan Suhaizan Kaiat (2002). " Pengaturcaraan orientasi Objek UML \& JAVA", Malaysia ; mcGraw-HILL (Malaysia) Sdn.Bhd.

2. Brek, A.A.(1985) “ LISP : The language Of Artificial Intelligence”: British Library Cataloguing in Publication Data.

3. Copyright maranGraphics Inc(2001) “PHP- your visual blueprint for creating open source, server-side content'.Wiley Publishing, Inc.

4. Deitel Deitel Nieto (2002), "Second Edition, Internet \& World Wide Web How To Program" Prentice Hall, Inc.

5. Gaithersburg, maryland, “ Renal Critical Care Nursing” Aspen Publisher, Inc.

6. Giarratano \& Riley (1998), “ Expert Systems Principles And Programming " PWS Publishing Company.

7. Janet kolodned (1993), "Case Based Reasoning”, Georgia institute of Technology.

8. Joseph Giarratano, Gary Riley (1998), “ Expert systems Principle ang Programming: third edition" : University of Houston clear lake, Calico Technology.

9. Julie C. Meloni (2003), "Sams Teach Yourself PHP, MySQL And Apache in 24 Hours" Sams Publishing.

10. Kenneth A.Bowen (1991), "Prolog \& Expert System", Applied logic Systems,inc and Syracuse University.

11. Mardhiyati Binti Ipin (2003)," Membangunkan Penaakulan Deduktif menggunakan Hujahan Berasaskan Peraturan : Mendiagnosis Penyakit Payudara Di peringkat Awal", Fakulti Sains Komputer dan Sistem Maklumat, Universiti Teknologi Malaysia. 
12. Nazaruddin Mazlan (2204), "Sistem Diagnosis Penyakit Denggi Menggunakan Teknologi PHP”, Fakulti Sains Komputer dan Sistem Maklumat, Universiti Teknologi Malaysia.

13. Patrick R.Harrison (1990);"Common LISP \& Atificial Intelligence", Printice-hall,Inc.

14. Rick F.van Der Lans(1993),"Introduction to SQL" Addison-Wesley Publishing Company.

15. Scott Mitchell, James Atkinson (2000),: "Teach Yourself Active Server Pages 3.0 in 21 Days" : Sams publishing

16. Suhaimi Ibrahim, Wan Mohd Nasir Wan Kadir, Paridah Samsuri, Rozlina Mohamed, Mohd yazid Idris (1999), “Kejuruteraan Perisian”, Skudai Johor Darul ta'azim : penerbit Universiti Teknologi Malaysia.

\section{Appendix A}

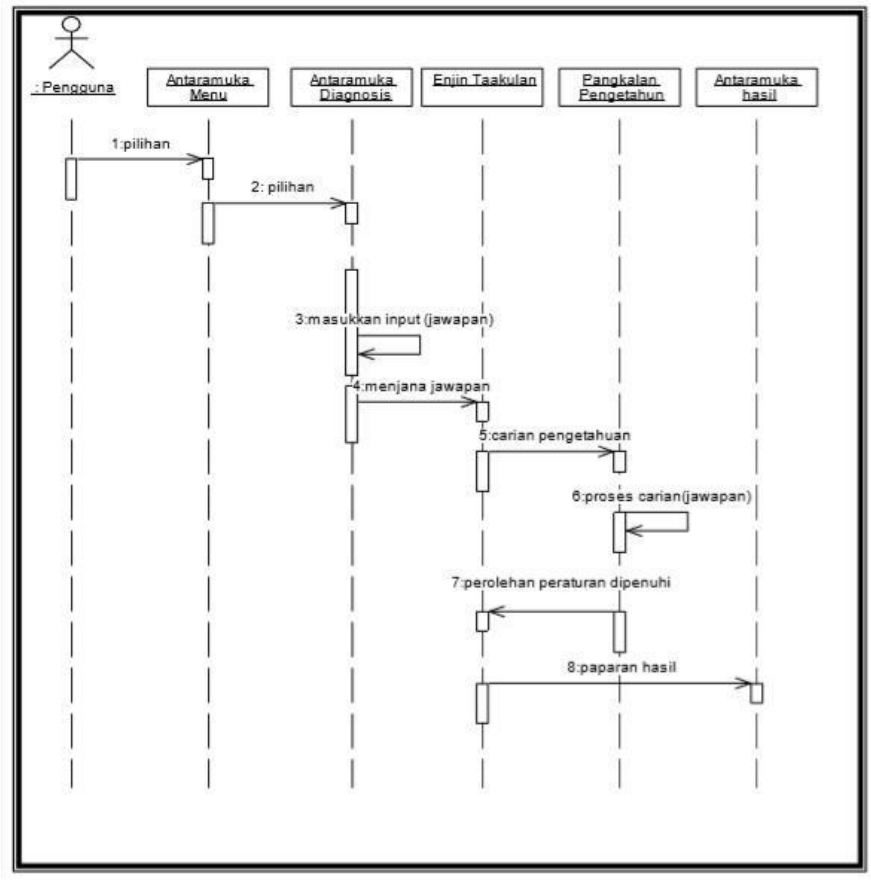

Figure 15: Sequence Diagram for Diagnosis

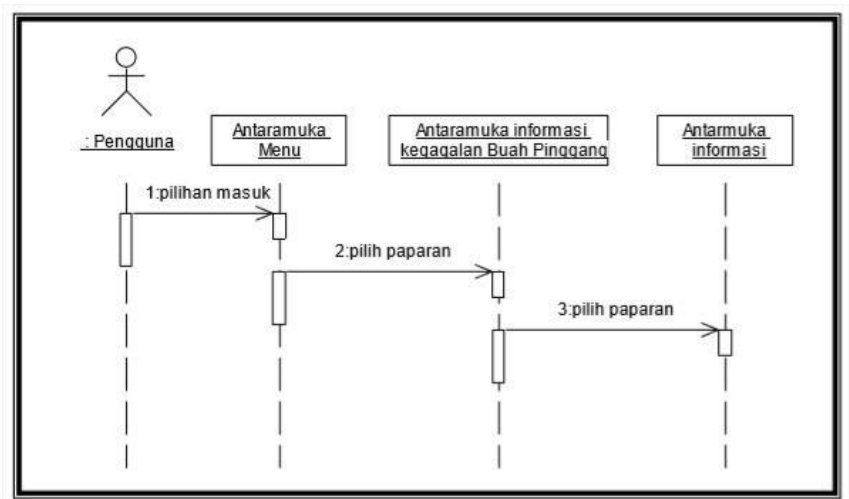

Figure 16: Sequence Diagram for Getting Information of Kidney Failure 


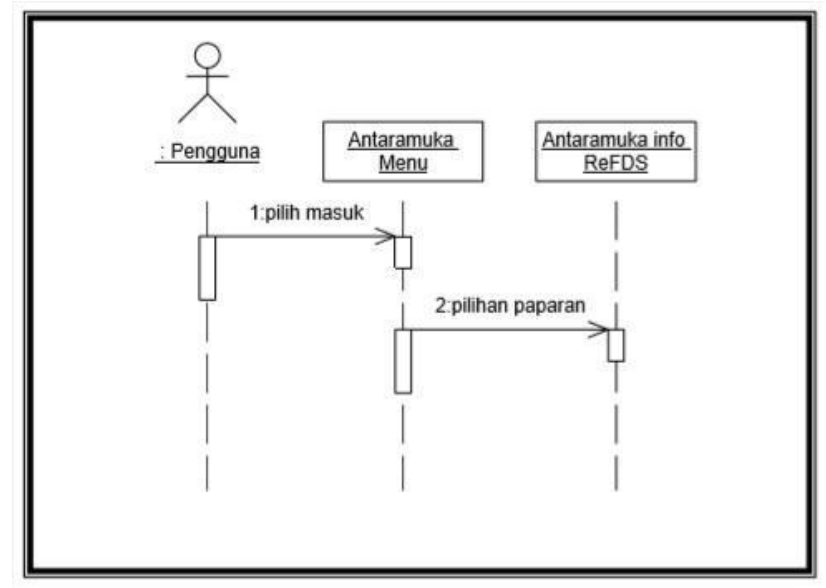

Figure 17: Sequence Diagram for Getting System Information (FeRDS)

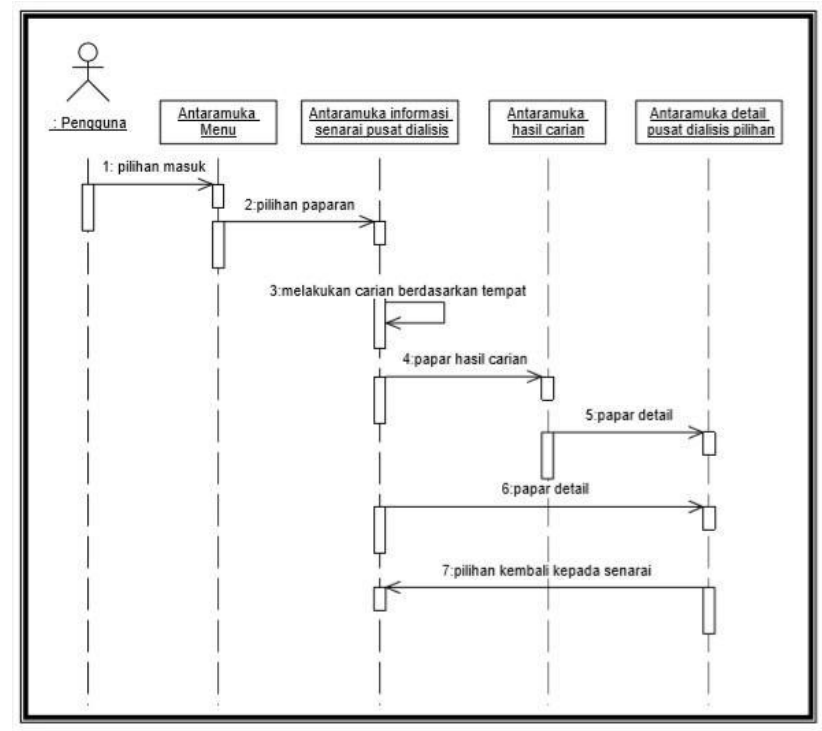

Figure 18: Sequence Diagram for Getting Dialysis Center Information 


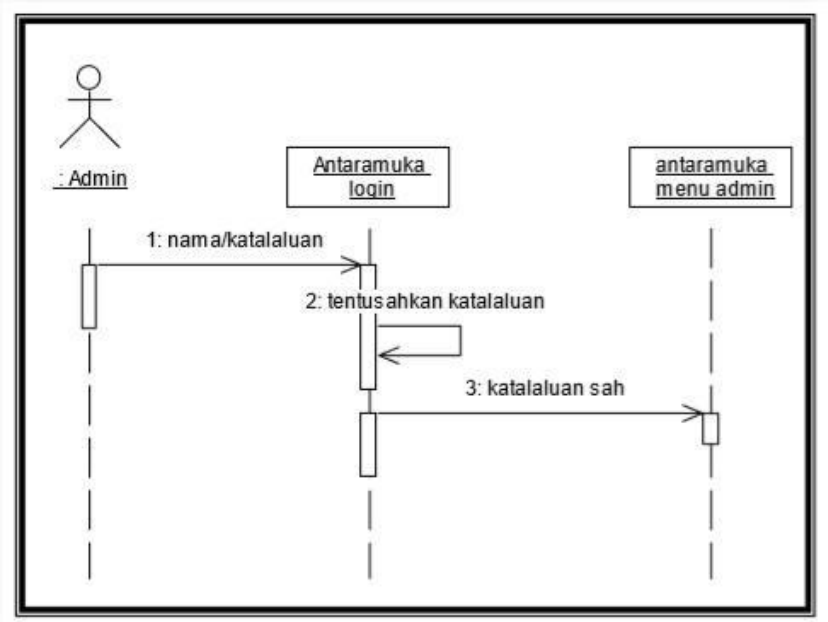

Figure 19: Sequence Diagram for Admin Login

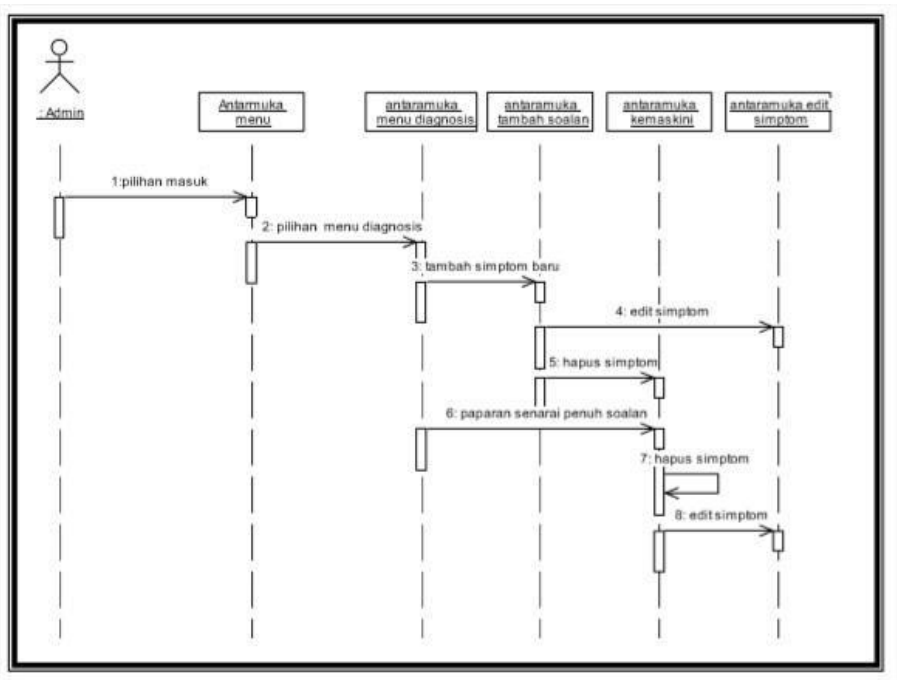

Figure 20: Sequence Diagram for Admin Choose Diagnosis Menu 


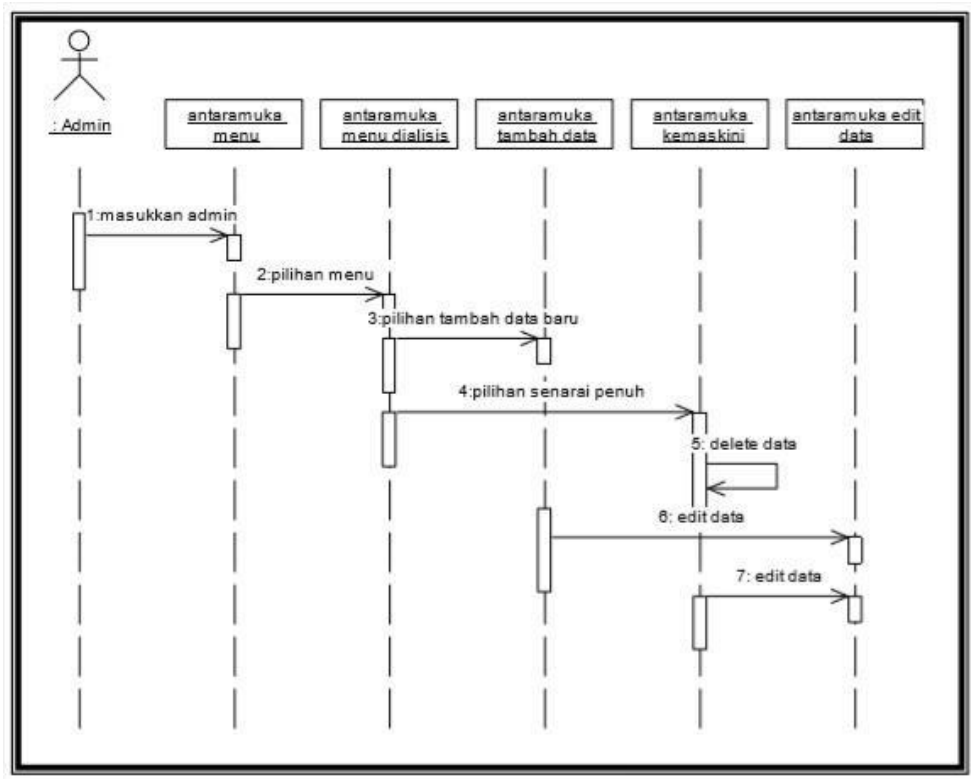

Figure 21: Sequence Diagram for Admin Choose Dialysis Menu

\section{Appendix B}

\begin{tabular}{|c|c|c|c|c|c|c|}
\hline \multicolumn{7}{|c|}{ Database dbdiagnosis - table ADMIN running on localhost } \\
\hline \multicolumn{2}{|c|}{ [Browse] } & [Select] I & [Insert] ] & [Empty] [ & [Drop] & \\
\hline & Field & Type & Attributes & ss Null Default & it Extra & Action \\
\hline$\Gamma$ & nama & varchar(15) & & No & & Change Drop Primary Index Unique Fulltext \\
\hline$\Gamma$ & pass & varchar(15) & & No & & Change Drop Primary Index Unique Fulltext \\
\hline
\end{tabular}

Figure 22: Admin Attributes Table

\begin{tabular}{|c|c|c|c|c|c|c|c|}
\hline \multirow[t]{2}{*}{ [Bre } & \multirow{2}{*}{$\begin{array}{l}\text { wse ] } \\
\text { Field }\end{array}$} & \multirow{3}{*}{$\begin{array}{l}\text { Select] [In } \\
\text { Type } \\
\text { int(3) }\end{array}$} & \multirow{3}{*}{$\begin{array}{l}\text { Insert] [E } \\
\text { Attributes }\end{array}$} & Empty] & \multicolumn{2}{|c|}{ [Drop] } & \multirow[b]{2}{*}{ Action } \\
\hline & & & & Null & Default & Extra & \\
\hline$\Gamma$ & idrekod & & & No & & auto_increment & Change Drop Primary Index Unique Fultext \\
\hline$\Gamma$ & idcenter & $\operatorname{varchar}(10)$ & & Yes & NULL & & Change Drop Primary index Unique Fultext \\
\hline$\Gamma$ & negeri & tent & & Yes & NULL & & Change Drop Primary Index Unique Fultent \\
\hline$\Gamma$ & nama & text & & Yes & NULL & & Change Drop Primary Index Unique Fultext \\
\hline$\Gamma$ & alamat & $\operatorname{tex}$ & & Yes & NULL & & Change Drop Primary Index Unique Fultext \\
\hline$\Gamma$ & bandar & text & & Yes & NULL & & Change Drop Primary Index Unique Fultent \\
\hline$\Gamma$ & poskod & varchar(10) & & Yes & NULL & & Change Drop Primary Index Unique Fultert \\
\hline$\Gamma$ & no_tel & varchar(15) & & Yes & NULL & & Change Drop Primary index Unique Fultent \\
\hline$\Gamma$ & no_fax & varchar(15) & & Yes & NULL & & Change Drop Primary index Unique Fultext \\
\hline$\Gamma$ & bayaran & varchar $(8)$ & & Yes & NULL & & Change Drop Primary index Unique Fultent \\
\hline$\Gamma$ & info & text & & Yes & NULL & & Change Drop Primary Index Unique Fultext \\
\hline
\end{tabular}

Figure 23: Attribute Table For Saving Dialysis Information 


\begin{tabular}{|c|c|c|c|c|c|c|c|}
\hline \multicolumn{8}{|c|}{ Database dbdiagnosis - table SEJARAH running on localhost } \\
\hline & Field & Type & Attributes & Null & Default & Extra & Action \\
\hline$\Gamma$ & id & tinyint(11) & & No & & auto_increment & Change Drop Primary Index Unique Fultex \\
\hline$\Gamma$ & sejarah & text & & No & & & Change Drop Primary Index Unique Fultext \\
\hline$\Gamma$ & keterangan & text & & No & & & Change Drop Primary Index Unique Fulltext \\
\hline$\Gamma$ & pemberat & int(11) & & No & 0 & & Change Drop Primary Index Unique Fulltext \\
\hline$\Gamma$ & sgt_kritikal & tinyint(1 1) & & Yes & 0 & & Change Drop Primary Index Unique Fultex \\
\hline
\end{tabular}

Figure 24: Attribute Table for Symptoms (Medical History)

\begin{tabular}{|c|c|c|c|c|c|c|c|}
\hline \multicolumn{8}{|c|}{ Database dbdiagnosis - table SIMPTOM running on localhost } \\
\hline & Field & Type & Attributes & Null & Default & Extra & Action \\
\hline$\Gamma$ & id & tinyint(11) & & No & & auto_increment & Change Drop Primary Index Unique Fulltext \\
\hline$\Gamma$ & simptom & text & & No & & & Change Drop Primary Index Unique Fulltext \\
\hline$\Gamma$ & keterangan & text & & No & & & Change Drop Primary Index Unique Fullteit \\
\hline$\Gamma$ & pemberat & int(11) & & No & 0 & & Change Drop Primary Index Unique Fulltext \\
\hline$\Gamma$ & sgt_kritikal & tinyint(11) & & No & 0 & & Change Drop Primary Index Unique Fulltext \\
\hline
\end{tabular}

Figure 25: Attribute Table for Symptom

\begin{tabular}{|c|c|c|c|c|c|c|c|}
\hline $\begin{array}{l}\text { Dat } \\
\text { (Bro }\end{array}$ & $\begin{array}{l}\text { abase } d k \\
\text { wse ] [Sel }\end{array}$ & diagnosi: & is - table & $\operatorname{tmp}$ & $\begin{array}{l}\text { p_ans! } \\
\text { [Drop }\end{array}$ & wer running & on localhost \\
\hline & Field & Type & Attributes & Null & Default & Extra & Action \\
\hline$\Gamma$ & idanswer & tinyint(11) & & No & & auto_increment & Change Drop Primary Index Unique Fultex \\
\hline$\Gamma$ & id & varchar(11) & & No & & & Change Drop Primary Index Unique Fultex \\
\hline$\Gamma$ & sejarah & teid & & No & & & Change Drop Primary Index Unique Fuitiex \\
\hline$\Gamma$ & pemberat & tinyint(11) & & No & 0 & & Change Drop Primary Index Unique Fulterd \\
\hline$\Gamma$ & P_input & tinyint(11) & & No & 0 & & Change Drop Primary Index Unique Fultext \\
\hline$\Gamma$ & sgt_kritikal & tinyint(11) & & No & 0 & & Change Drop Primary Index Unique Fultex \\
\hline
\end{tabular}

Figure 26: Attribute Table For Tmp_Answer (Temporary Table That Keeps Answers From Users)

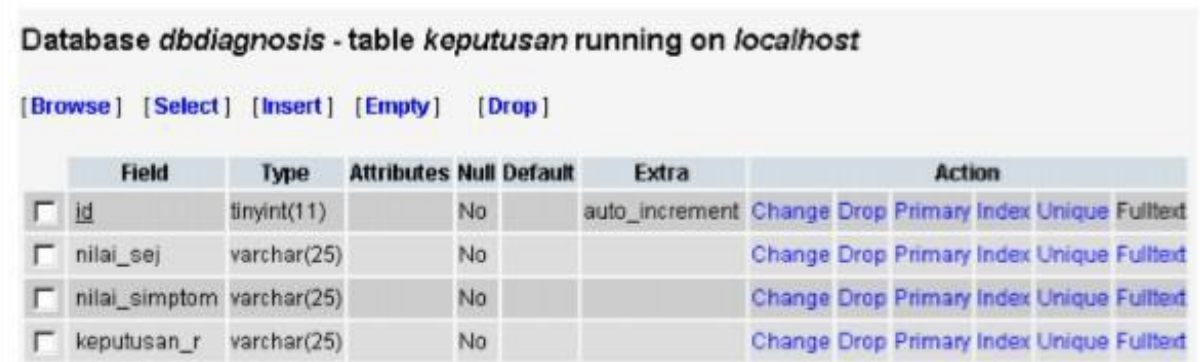

Nuraini Abdullah et.al (Management System Development of Diagnistic Imaging in Batu Pahat Hospital 
Figure 27: Attribute Table for Diagnosis Result

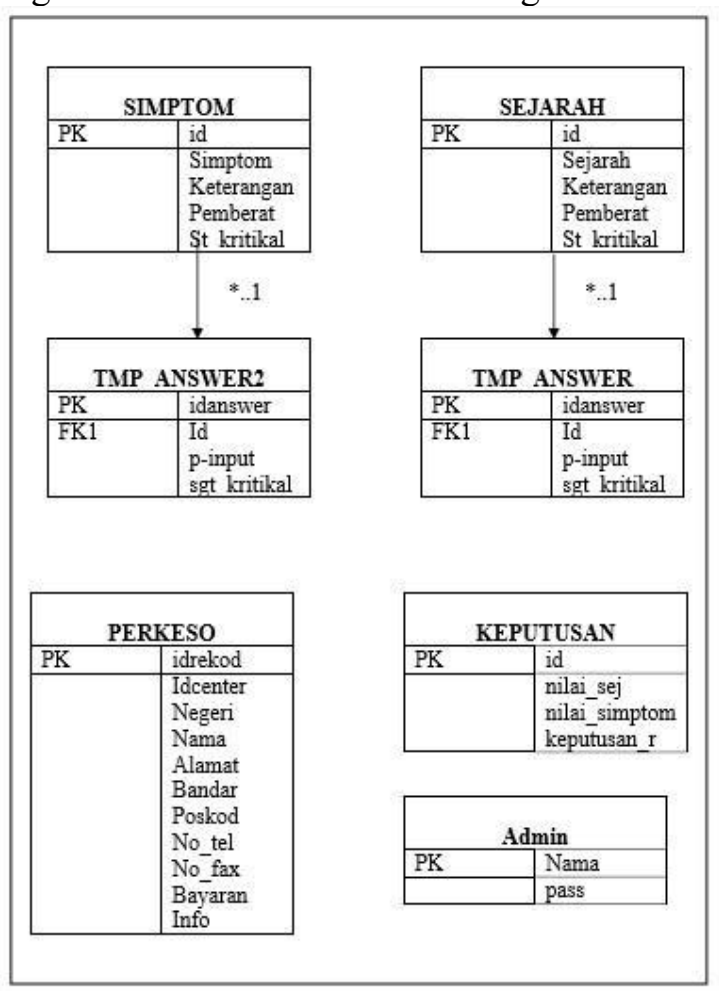

Figure 28: Entity Relationship Database For ReFDS

\section{Appendix C}

\begin{tabular}{|l|l|l|l|}
\hline Bil & Input & Output Jangkaan & $\begin{array}{l}\text { Output } \\
\text { Sebenar }\end{array}$ \\
\hline 1. & $\begin{array}{l}\text { Carian melalui medan } \\
\text { Bandar pada menulist }\end{array}$ & $\begin{array}{l}\text { Terima Input carian ke pangkalan data, } \\
\text { Paparkan carian Bandar yang dipilih }\end{array}$ & Diuji, OK \\
\hline 2. & Carian melalui medan negeri & $\begin{array}{l}\text { Terima Input carian ke pangkalan data, } \\
\text { Paparkan carian Bandar yang dipilih }\end{array}$ & Diuji, OK \\
\hline 3. & Klik pada icon 'detail' & Paparkan maklumat yang dipilih & Diuji, OK \\
\hline 4. & Klik 'link' pada laman & Semua link berfungsi & Diuji, OK \\
\hline
\end{tabular}

Figure 29: Unit Testing for Search Dialysis

\begin{tabular}{|l|l|l|l|}
\hline Bil & Input & Output Jangkaan & $\begin{array}{l}\text { Output } \\
\text { Sebenar }\end{array}$ \\
\hline 4. & Klik 'link' pada laman & Semua link berfungsi & Diuji, OK \\
\hline
\end{tabular}

Figure 30: Unit Testing for Information 


\begin{tabular}{|l|l|l|l|}
\hline Bil & Input & Output Jangkaan & $\begin{array}{l}\text { Output } \\
\text { Sebenar }\end{array}$ \\
\hline 1. & Input sah & Terima Input ke pangkalan data. & Diuji, OK \\
\hline 2. & Input tidak sah & $\begin{array}{l}\text { Mustahil kerana pilihan input } \\
\text { disediakan oleh pembangun }\end{array}$ & Diuji, OK \\
\hline 3. & Klik 'link' pada laman & Semua link berfungsi & Diuji, OK \\
\hline
\end{tabular}

Figure 31: Unit Testing for Diagnosis

\begin{tabular}{|l|l|l|l|}
\hline Bil & Input & Output Jangkaan & $\begin{array}{l}\text { Output } \\
\text { Sebenar }\end{array}$ \\
\hline 1. & Katalaluan dan nama sah & $\begin{array}{l}\text { Terima Input carian ke pangkalan data, } \\
\text { Sah : Paparkan link menu pada ruangan } \\
\text { info. }\end{array}$ & Diuji, OK \\
\hline 2. & $\begin{array}{l}\text { Katalaluan dan nama tidak } \\
\text { sah }\end{array}$ & $\begin{array}{l}\text { Tidak sah : paparkan ralat pada ruangan } \\
\text { info. }\end{array}$ & Diuji, OK \\
\hline 3. & Klik 'link' pada laman & Semua link berfungsi & Diuji, OK \\
\hline
\end{tabular}

Figure 32: Unit Testing for Login Module

\begin{tabular}{|l|l|l|l|}
\hline Bil & Input & Output Jangkaan & $\begin{array}{l}\text { Output } \\
\text { Sebenar }\end{array}$ \\
\hline 1. & $\begin{array}{l}\text { Tambah pusat dialisis } \\
\text { (i) Input sah }\end{array}$ & $\begin{array}{l}\text { (i)Terima Input carian ke pangkalan } \\
\text { data, } \\
\text { pergi ke antaramuka paparan } \\
\text { masukkan data }\end{array}$ & Diuji, OK \\
(ii) Input tidak sah & $\begin{array}{l}\text { (ii) Mustahil, sistem menerima semua } \\
\text { input yang dimasukkan }\end{array}$ & Diuji, OK \\
\hline Klik ikon 'edit' & $\begin{array}{l}\text { Antaramuka edit dipaparkan. Data } \\
\text { kemaskini diterima. }\end{array}$ & Diuji, OK \\
Klik ikon 'delete' & $\begin{array}{l}\text { Kembali ke laman kemaskini. } \\
\text { Penghapusan dari pangkalan data. } \\
\text { 3. }\end{array}$ & $\begin{array}{l}\text { Semua link berfungsi } \\
\text { Klik 'link' pada laman }\end{array}$ & Diuji, OK \\
\hline
\end{tabular}

Figure 33: Unit Testing for Update Dialysis Module 


\begin{tabular}{|l|l|l|l|}
\hline Bil & Input & Output Jangkaan & $\begin{array}{l}\text { Output } \\
\text { Sebenar }\end{array}$ \\
\hline 1. & $\begin{array}{l}\text { Tambah simptom } \\
\text { Input sah }\end{array}$ & $\begin{array}{l}\text { Terima Input ke pangkalan data, } \\
\text { pergi ke antaramuka paparan } \\
\text { masukkan simptom. }\end{array}$ & Diuji, OK \\
\hline
\end{tabular}

\begin{tabular}{|l|l|l|l|}
\hline & Input tidak sah & $\begin{array}{l}\text { (ii) Mustahil, sistem menerima semua } \\
\text { input yang dimasukkan }\end{array}$ & Diuji, OK \\
\hline 2. & $\begin{array}{l}\text { Kemaskini simptom } \\
\text { Klik ikon 'edit' }\end{array}$ & $\begin{array}{l}\text { Antaramuka edit dipaparkan. Data } \\
\text { kemaskini diterima. }\end{array}$ & Diuji, OK \\
Klik ikon 'delete' & $\begin{array}{l}\text { Kembali ke laman kemaskini. } \\
\text { Penghapusan dari pangkalan data. }\end{array}$ & Diuji, OK \\
\hline 3. & Klik 'link' pada laman & Semua link berfungsi & Diuji, OK \\
\hline
\end{tabular}

Figure 34: Unit Testing for Update Diagnosis Module

\begin{tabular}{|l|l|l|l|}
\hline Bil & Input & Output Jangkaan & $\begin{array}{l}\text { Output } \\
\text { Sebenar }\end{array}$ \\
\hline 1. & Klik 'link' pada laman & Semua link berfungsi & Diuji, OK \\
\hline
\end{tabular}

Figure 35: Unit Testing for Main System 